\title{
Creating Public Awareness of Renewable Energy by Combining a Photovoltaic System and Nature
}

\author{
Arnold Knott $^{1} \quad$ Dorthe Hedensted Lund $^{2} \quad$ Thomas Andersen $^{1}$ \\ ${ }^{1}$ Technical University of Denmark \\ DTU Elektro \\ Ørsteds Plads, bygning 349 \\ DK-2800 Kgs. Lyngby, Denmark \\ +45 452534 90, akn@elektro.dtu.dk \\ ${ }^{2}$ University of Copenhagen \\ Forest \& Landscape, Faculty of Life Sciences \\ Rolighedsvej 23 \\ DK-1958 Frederiksberg C, Denmark \\ +45353316 97, dhl@life.ku.dk
}

+45452534 71, ta@elektro.dtu.dk

\begin{abstract}
Energy is seemingly permanently and nearly everywhere in the western world available to the end consumer. While a majority of the western civilization is aware of the downsides of fossil energy sources and is favoring renewable energy sources, the energy consumption is still increasing. The situation is quite clear to the experts in the field, but further awareness in the public must be created. Therefore this paper addresses a method of creating this awareness: installations that stimulate conversations of renewable energy.

A solar tree was developed and built to serve young people with an AC outlet at a rock festival. The tree was realized under mechanical constraints and considerations of the electrical network to allow energy storage and conversion. This paper will introduce the principle of provotypes, which are provoking human thinking toward environmental friendly technology. The mechanical requirements and the developed solution is shown, before providing intensive insight into the electrical configuration, consisting of a battery, photovoltaic cells and a DC-AC converter. Furthermore a low complexity charge controller is presented. The resulting solar tree is capable of attracting peoples attention, surviving in harsh environments and providing power up to around $100 \mathrm{~W}$.
\end{abstract}

\section{Key words}

Solar Energy, Technology Social Factors, DC-AC Power Conversion, Capacitive Energy Storage, Provotypes

\section{Introduction}

Engineering communities in universities and private companies are putting many resources into the development of efficient renewable energy technologies, and clean tech development is furthermore receiving political focus in environmental and research policies 11. In the latest parliament settlement in Denmark energy and environment is one of five strategic research areas [2], and clean tech also plays a prominent role in a recent report of a government instituted climate commission 3]. In portuguese public institutions, i.e. universities and museums, the public was introduced to renewable energy sources through a solar festival
[4. However, to further promote renewable energy there needs to be created extended awareness of the available technologies among citizens.

Roskilde festival, the largest rock festivals in Northern Europe, has designated a part of the festival area to promote environmental awareness among the 75.000 guests and 25.000 volunteer workers. Here volunteers place various sorts of installations aiming to illustrate and inform of environmental problems and possible solutions 57. Renewable energy technologies are part of these solutions, and this paper deals with the development and production of an installation combining photovoltaic panels and biomass to raise awareness of these energy forms.

In the field of Human Computer Interaction (HCI) researchers and engineers have been working with Tangible User Interfaces (TUI) and Tangible Interaction (TI) for a while. These terms denote efforts to embed computing in the everyday environment of users in a material form in a manner where the user can interact physically with the computational resource which this way becomes intuitively accessible. Museums and artist experiment with TI as a means to make exhibition and museum visitors interact in order to develop the museum experience, product designers and architects create interactive spaces and products to induce meanings into products and reactive behaviour 6]. Artefacts in TI installations can be so-called provotypes [7] that provoke certain themes in the conversations of the interacting persons 8 . The described photovoltaic system in this paper aims to provoke the theme of renewable energy by means of a TI inspired installation at Roskilde Festival 2010.

Taking departure in nature and plants and how they transform the energy of the sun into biomass, we developed the idea of building a large tree that transformed solar energy to electricity by means of solar panels and had an AC outlet at the stem. Here festival guests could charge their mobile phones, and while the phones recharge, the guests were confined to the vicinity of the tree in order to keep an eye on their 
phones. Our aim was that the installation in itself combined with some information on the stem of the tree regarding energy from photovoltaic panels and biomass would trigger a conversation and raise awareness about these themes. The concept of the tree is shown in figure 1

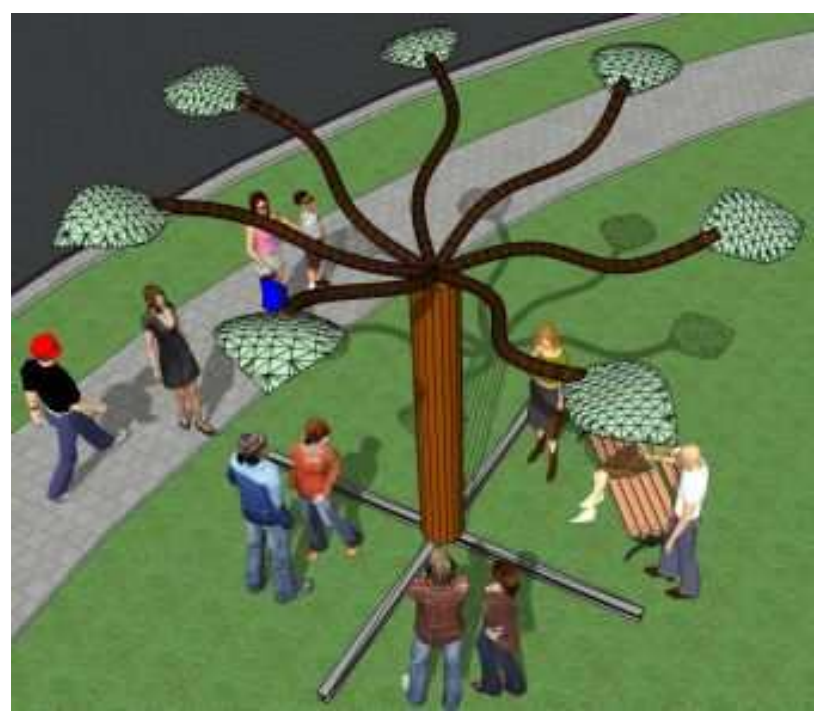

Figure 1: Concept drawing of the solar tree, showing the wooden stem, iron roots and the photovoltaic cells on top of the leaves.

\section{Mechanical Construction}

The conditions of Roskilde Festival call for several demands on the mechanical construction. Firstly Roskilde Festival is populated by about 100.000 people with an average age of around 20, who are attending the festival to enjoy rock music. Along with this, the alcohol consumption is quite high. Therefore the solar tree installation is required to be vandal-proof. To ensure that the electrical system of the installation is protected against vandalism, we decided, that the stem should be higher, than two persons, one sitting on the shoulder of the other, could not reach up to the photovoltaic cells and the the electronics, which were installed in a water-proof box on top of the stem. This requirement resulted in a stem length of $3 \mathrm{~m}$.

The festival lasts for one week at the end of June and beginning of July and is situated in a geographic area with various possible weather conditions. Rainy days, storm and sunshine are all possible conditions. While operation was only required during sunshine, it was desired, that the whole installation could withstand all the other conditions without damage.

To make the installation water-proof, the electrical components where encapsulated in an IP66 proof case on top of the stem and the photvoltaic cells were hermetically closed between a glass panel and a foil.

For ensuring the installation to be wind-proof, the actual tree was split in half and an iron stem was constructed as shown in figure 2. The $3 \mathrm{~m}$ long roots of the skeleton are intended to be buried in the ground to provide mechanical stability under stormy weather conditions. On top of the iron stem, eight branches were planned to be welded to stem. Here the natural branches where mounted with bolts.

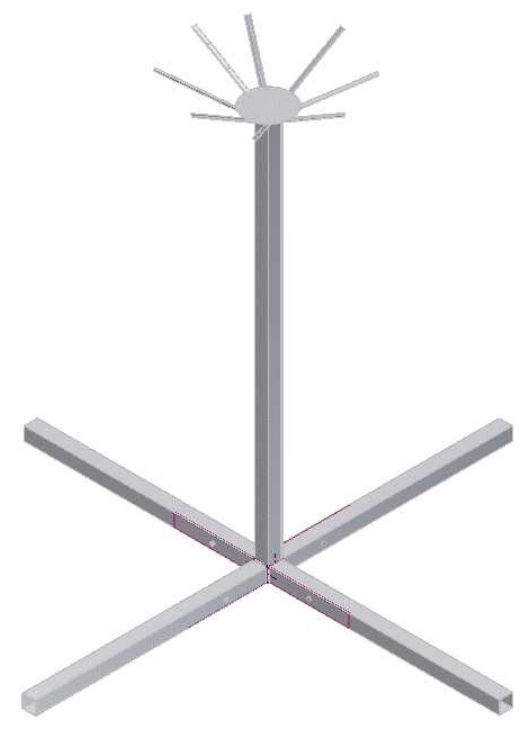

Figure 2: The iron welded skeleton of the tree, containing rectangular iron profiles with $120 \mathrm{~mm}$ in diameter and a thickness of $5 \mathrm{~mm}$

As the crown of the tree was spanning around $5 \mathrm{~m}$ and the diameter of the area, the construction occupied on ground was $6 \mathrm{~m}$ the tree had to be transportable. Furthermore it was required, that both the roots and the branches had to be detachable. Furthermore, the tree was designed to get reused in other public places after the festival to create awareness of renewable energy among even more citizens. Therefore both, the natural branches with the artificial leaves and the iron roots where made detachable. The mounting strategy of the roots with its bolts is shown in figure 3. This way, the maximum diameter of the skeleton was $1.5 \mathrm{~m}$ with a length of $3 \mathrm{~m}$, which enabled transportation of the construction on a truck.

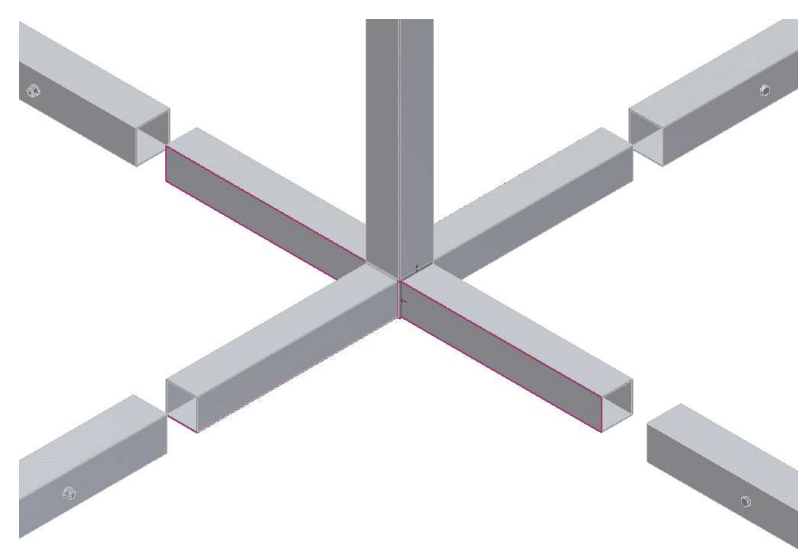

Figure 3: The long iron roots where made to impose on the $700 \mathrm{~mm}$ short roots, which where welded to the iron stem. Through bolts the long roots where fixed to the short ones. 


\section{Electrical Design}

Next the electrical design had to fulfill certain demands. It was expected, that the load of the generator and the energy harvesting through the photovoltaic cells was not correlated, similarly to the problem described for traffic solar driven lights in 9 . That means, that users would use the $\mathrm{AC}$ outlet at times, where the sky was cloudy and therefore the source would not deliver enough energy. On the other hand, there were periods, where the energy harvesting of the cells was higher than the energy consumption. We decided to include an energy storage device to allow for maximum energy harvesting instead of instantaneous power delivery only.

The harvested energy from the photovoltaic sources had to be converted into a standard AC mains voltage, so that the end users could apply their standardized electric equipment. As the festival took place in Europe, it was decided to provide $230 \mathrm{~V}$ at $50 \mathrm{~Hz}$. A standard DC-AC converter was used for this. Its automotive input voltage range from $9 \mathrm{~V}$ to $16 \mathrm{~V}$ set the requirements for the common DC voltage link between the photovoltaic cells, the battery and the converter. By design of the photovoltaic panels, it was guaranteed, that the overvoltage lockout of the converter could not be reached. According to equation 1, the maximum number of possible photovoltaic cells in series $N$ can be determined through the minimum overvoltage lockout of the converter $V_{O V L O_{m i n}}$ and the maximum forward voltage drop of the photovoltaic cells internal diode $V_{\text {diode }_{\max }}$.

$$
N \leq \frac{V_{O V L O_{\min }}}{V_{\text {diode }_{\max }}}
$$

For the used converter and cells, the design ended up with $N=24$. As each of the branches on the tree carried one panel, and there was physical room for 8 branches, there were also 8 panels in parallel.

The undervoltage case is not a problem for the converter, because it had an internal shutdown and surveillance function to ensure defined start-up and shut-down. However the battery on the DC bus had to be prevented from complete discharge at night through the cells and the converters standby losses. As opposed to the charge controllers presented in [10, 11 the presented system in this paper was designed to guarantee failure free operation between the photovoltaic cells and the converter and therefore only had the need for a charge controller to detach the battery. Firstly this prevents the battery from getting completely discharged and secondly the circuit breaker prevents energy dissipation in the photovoltaic cell when the voltage on the DC bus is provided from the battery. In the later case the photovoltaic cell will act as load and dissipate power. The used photovoltaic cells were characterized in the expected operating voltage range and shown in figure 4.

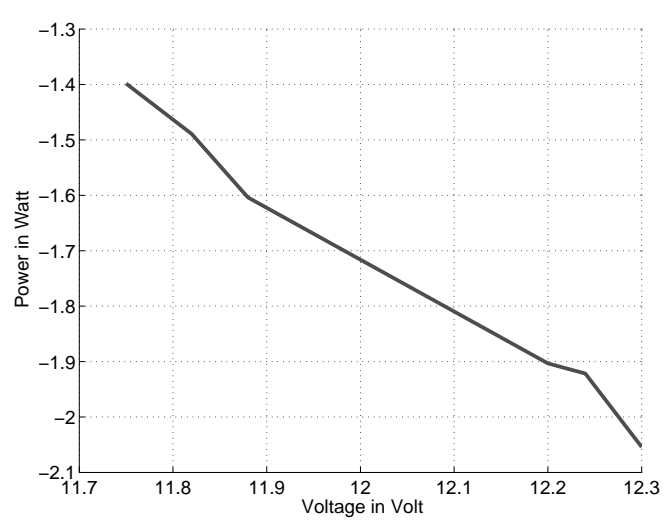

Figure 4: Measurement of the power dissipation in one photovoltaic panel, when operated in fourth quadrant.

All these considerations result in the block diagram of the electronics as shown in figure 5]
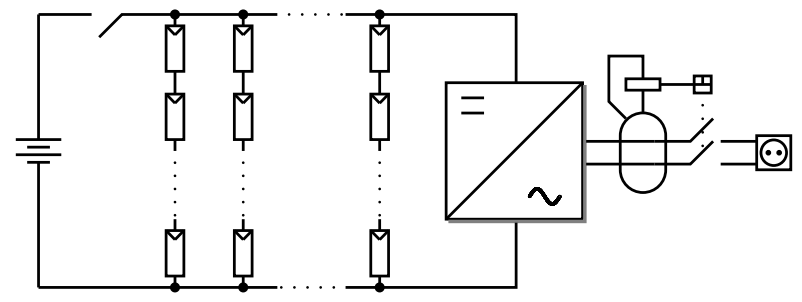

Figure 5: Block diagram illustratively showing the connection between the battery, charge controller, photovoltaic panels and the DC-AC converter.

It is desired, that the shown switch in this block diagram contains a hysteresis to avoid bouncing, when the accumulated voltage of the photovoltaic panels approaches the voltage of the battery. On the output side a residual current circuit breaker (RCCB) (equally to a ground fault interrupter (GFI)) is protecting the user accessible power socket.

\section{Realization}

The designed tree was realized consisting out of the metal welded stem, the real tree stem mounted around it, real branches carrying artificial leaves with the photovoltaic cells fixed to them and the electronics in a water-proof box on top of the stem.

\section{A. Mechanical}

Figure 6 shows the branches and the leaves acting as physical carrier for the photovoltaic panels.

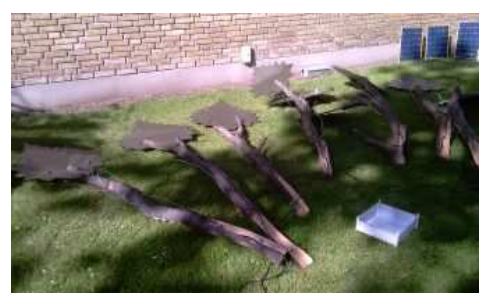

Figure 6: The natural branches holding the artificial leaves. 
On top of the leaves the fixtures for the photovoltaic panels can be seen. The lid in the front is part of the water-proof chassis for the electronics. Three of the photovoltaic panels are in the background.

The mechanical construction without the removable long roots can be seen in figure 7

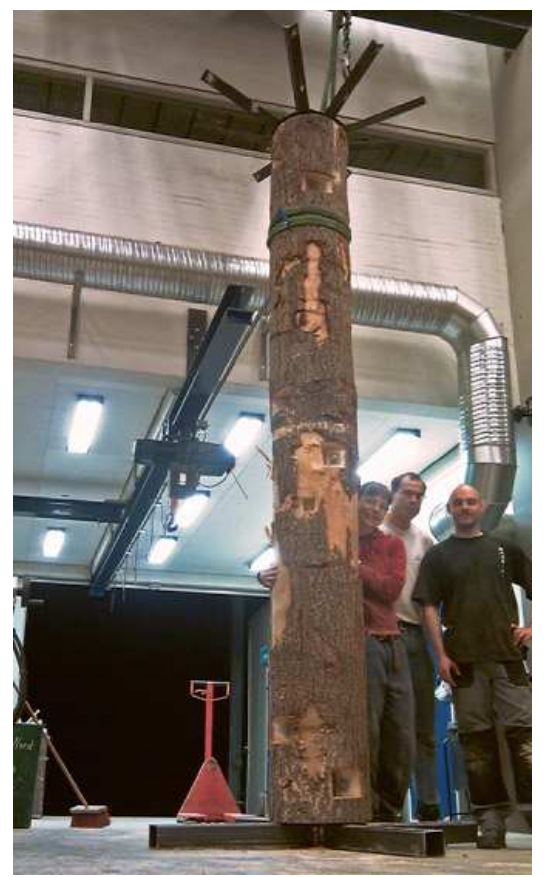

Figure 7: The natural stem is covering the metal skeleton from figure 2 ,

\section{B. Electrical}

The charge control circuit, as presented in section 3 . was implemented in a low complexity discrete circuit as shown in figure 8 .

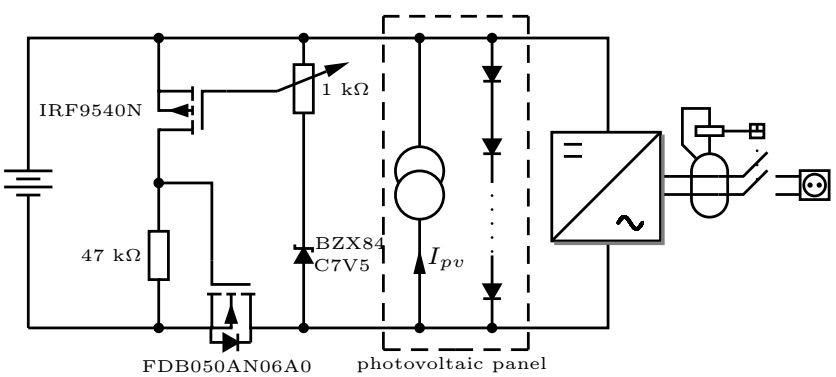

Figure 8: Complete schematic for detachment of the battery to prevent its discharge.

As the application is always outdoor and the weather conditions can be expected to be harsh, the circuit was implemented with automotive qualified components only, which have a high operating temperature range, as can be seen from table 1 .

Table 1: Operating junction temperature ratings of the used semiconductor devices

\begin{tabular}{|c|c|c|}
\hline DEVICE & $\vartheta_{\min }$ & $\vartheta_{\max }$ \\
\hline IRF9540N & $-55^{\circ} \mathrm{C}$ & $175^{\circ} \mathrm{C}$ \\
\hline FDB050AN06A0 & $-55^{\circ} \mathrm{C}$ & $175^{\circ} \mathrm{C}$ \\
\hline BZX84-C7V5 & $-55^{\circ} \mathrm{C}$ & $150{ }^{\circ} \mathrm{C}$ \\
\hline
\end{tabular}

The circuit operates in the following modes:

\section{1) Day}

The voltage across the photovoltaic panels is defining the DC bus voltage. The gate reference voltage for the p-channel MOSFET, which can be trimmed by the potentiometer between $7.5 \mathrm{~V}$ (the zener diode voltage) and $16 \mathrm{~V}$ (the absolute maximum output voltage of the panels), is higher than the MOSFETs gate-threshold voltage. Therefore the p-MOSFET is in saturation and conducting the gate of the n-channel MOSFET to the positive voltage of the battery, so the $\mathrm{n}$-channel MOSFET is turned on as well. Energy is delivered from the panels to both, the battery and the converter.

\section{2) Sunset}

The energy delivery from the panels is falling, however the battery which is connected in parallel with the panels through the $n$-channel MOSFET is keeping the voltage and delivering the required energy. As the battery is not getting recharged, the voltage across the battery drops. This also happens when the panels are shaded for a short period of time, e.g through clouds. As soon as the voltage is lower than the under voltage lockout of the converter, it automatically turns off. Now there is still a current path from the battery through the panels and the turned on n-channel MOSFET back to the battery. The power as shown in figure 4 is dissipated in the cells. As this is undesired, the potentiometer is adjusted in a manner, so that the gate threshold voltage of the p-channel MOSFET cannot be sustained in this mode. The fixed value resistor is pulling the n-channel MOSFETs gate to its source and both MOSFETs is turning off.

\section{3) Night}

The voltage across the photovoltaic panels is lower than the battery voltage and the converter is in undervoltage lockout mode. Therefore, there is no electricity available at the $\mathrm{AC}$ outlet.

\section{4) Sunrise}

The voltage across the panels rises. As soon as the converters undervoltage lockout hysteresis voltage is exceeded, the converter turns on and delivers energy to the socket. The panels voltage need to exceed the actual voltage of the battery plus the forward voltage drop of the n-channel MOSFET. For a while, the voltage across the potentiometer is not high enough and the current will continue conducting through the n-channels body diode. This way, the body diodes forward voltage drop is used to generate the turn-on hysteresis. The same scenario is given for a load jump (from heavy to light load) under constant illumination of the photovoltaic panels. As soon as the voltage in the battery is rising high enough to cause enough voltage drop across the potentiometer and therefore 
the p-channel MOSFET conducts, the circuit is going over into day-mode and a new cycle begins. Figures 9 and 10 illustrate a simulated day with the according signals in the circuit.

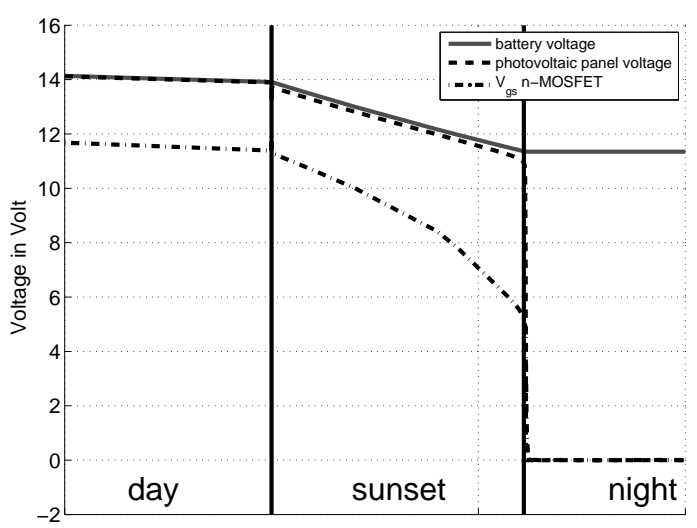

Figure 9: The voltage on the DC bus is dropping, which is finally causing the p-channel to turn off and detach the battery. The duration of the period called sunset is strongly dependent on the load on the socket.

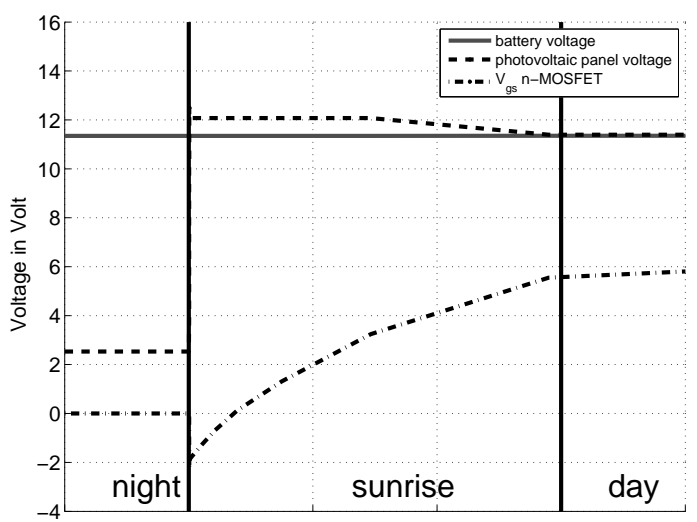

Figure 10: After the amount of energy delivered by the photovoltaic panels rises, the body diode conducts and starts to be clamp by the battery voltage until finally the charge controllers MOSFETs are turned on and the controller transfers into day mode.

The measured characteristics of the used panels is shown in figure 11.

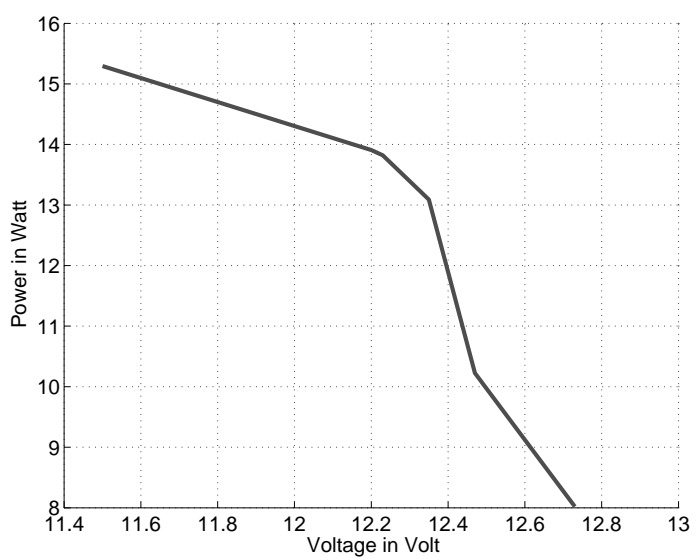

Figure 11: Measurement of a photovoltaic panel, when operated as a generator in the first quadrant.

\section{Social Impact}

After construction, the tree was firstly tested at the local conference Grøn Dyst at the Technical University of Denmark where it was visited by the Danish Minister for Climate and Energy. After that, it was demounted and transported to the Roskilde Festival 2010, where it served as a meeting point, point of departure for many discussions and as electrical energy source. A scene from the festival is shown in figure 12 .

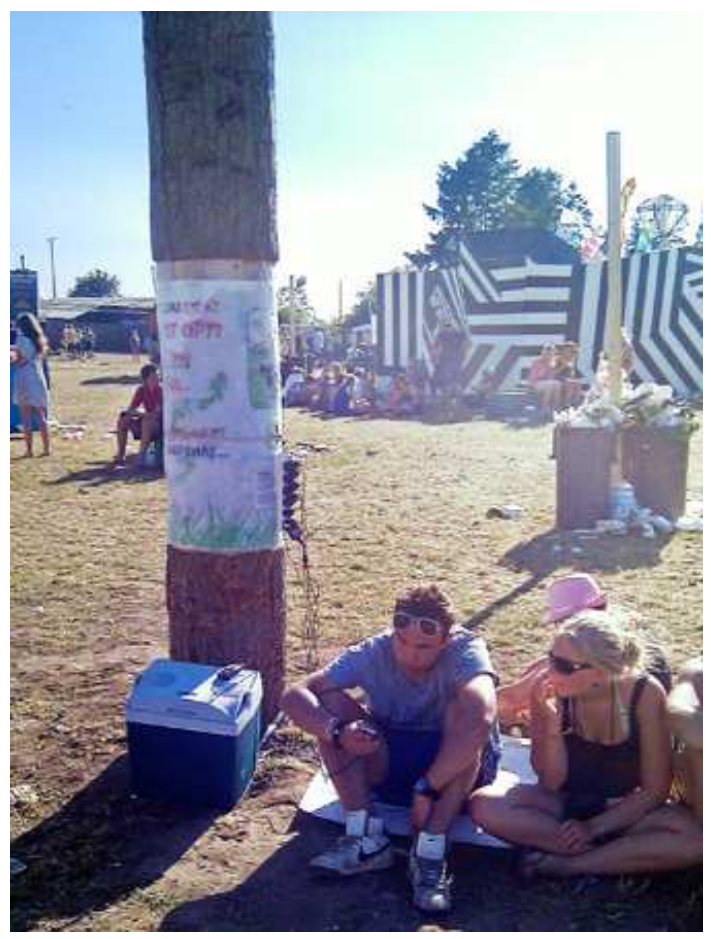

Figure 12: Young people at the Roskilde Festival 2010, using the renewable energy from the solar tree to recharge their mobile phones and cool their drinks.

After the rock festival, the solar tree caught attention from the neighboring country Sweden, where it was loaned out for the Kulturfestival in Stockholm, so it was demounted and transported again, this time around $600 \mathrm{~km}$. After this event, the tree came back to Denmark and is since then located at the Technical University of Denmark (figure 13) in the vicinity of natural trees and reminding students on the technical influence on a greener future.

\section{Conclusion}

At the background of creating awareness of the climate debate and the problem of fossil energy resources, a so called provotype was developed. Its purpose is to provoke discussion among the public and generating a deeper mindset on renewable energy.

Therefore a mechanical construction for a solar tree was developed and realized to catch the attention of around 100.000 guests at a rock festival.

Mechanically, the construction fulfills the requirements of being vandal-proof and is capable of surviving various weather conditions like rain, storm and 


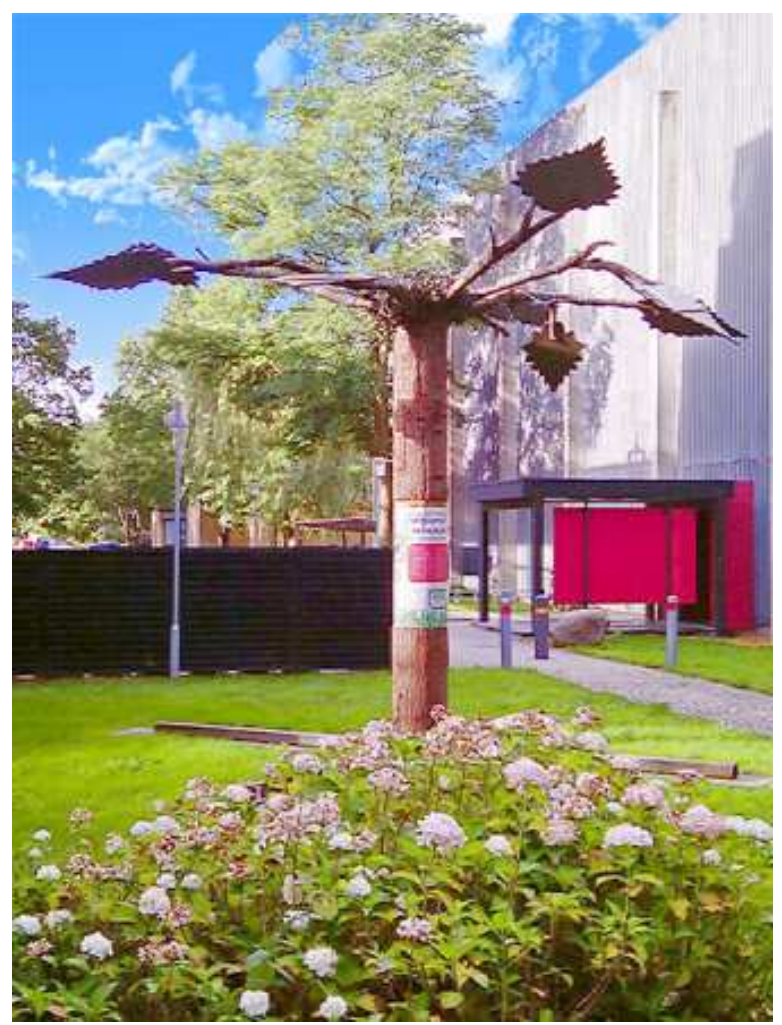

Figure 13: The solar tree in its location at the Technical University of Denmark

certainly sunshine. Furthermore the construction was deployed in a manner, so that it can be transported and reused to attract even more people to the climate discussion.

Electrically a low complexity charge circuit was simulated, built, tested and applied to the solar tree. The circuit is in charge of controlling the battery voltage and preventing complete discharge of the battery. Furthermore the system was implemented in a manner to be self-protective in terms of overvoltage and the system is intrinsically overload protected. For avoiding bounce when attaching the battery, the body diode of a MOSFET is used to create hysteresis voltage.

Socially the solar tree had an international impact on a local renewable energy students conference, where it was used as a demonstrator, addressed around 100.000 people at the Roskilde Festival 2010 in Denmark and furthermore the 300.000 guests at Stockholm Kulturfestival. Finally the solar tree is reminding the engineering students at the Technical University of Denmark on the climate debate and the use of renewable energy sources.

\section{Acknowledgements}

We like to thank Roskilde Festival, Jens Martin Dandanell at DTU byg, Bertil Morelli at DTU Elektro, Anders from Erik Larsen, Anders Hyldgård from Sunsil, Anders Neergaard Jacobsen from Forestry College KU and Gabrielle Janslev for their support.

\section{References}

[1] C. Redondo Gil; L.A. Esquibel; A.M. Alonso Sánchez. European strategic energy technology plan. Renewable Energy \& Power Quality Journal, 7, April 2009.

[2] Aftale mellem regeringen, Socialdemokraterne, Dansk Folkeparti og Det Radikale Venstre. Fordeling af globaliseringsreserven til forskning og udvikling 2011-2012.

[3] Klimakommissionen. Grøn Energi - Vejen mod et dansk energisystem uden fossile brændsler.

[4] Iolanda Sousa; Hernâni Alcobia; Paulo Pereirinha. Solar Festival-Renewable Energy Awareness for Microproduction and Building Integration. Renewable Energy $\&$ Power Quality Journal, 8, April 2010.

[5] K. Lindberg-Poulsen, M. A. E. Andersen, A. Knott, T. Andersen. Energy harvesting from an exercise bike using a switchmode converter controlled generator. IEEE Int. Conference on Sustainable Energy Technologies, 2010.

[6] Eva Hornecker; Jacob Buur. Getting a grip on tangible interaction: a framework on physical space and social interaction. Proceedings of the SIGCHI conference on Human Factors in computing systems, 2006.

[7] Preben Hols Mogensen. Challenging Practice an approach to Cooperative Analysis. $\mathrm{PhD}$ thesis, Datalogisk Institut, Århus, December 1993.

[8] Jacob Buur; Larisa Sitorus. Ethnography as Design Provocation. Ethnographic Praxis in Industry Conference Proceedings, 2007(1):146-157, October 2007.

[9] Hassan Moghbelli; Khaled Ellithy; Zohreh Eslami; R. Vartanian; D. Wannous; A. Fayad; O.Basha; A.El Ghamrawy; M.Qaraqe; S. Nicola. Investigation of solar energy applications with design and implementation of photovoltaic traffic light signal system. Renewable Energy \& Power Quality Journal, 7, April 2009.

[10] Campayo Martín, J.J.; Ramos Hernanz, J.A.; Zamora Belver, I.; Larrañaga Lesaka, J.; Zulueta Guerrero, E.; Motrico Gogeaskoetxea, J. Photovoltaic system behaviour with different loads. Renewable Energy \& Power Quality Journal, 8, April 2010.

[11] A. Daniel Rey Rey; B. Manuel Alejandro Miguez Ruanova; C. Francisco Manuel León Mayo; Iago Fernández Otero; Vicente Gándara Villadoniga; A. López Agüera. Solar mixed thermal and photovoltaic installation for an infantile educationalsanitary lodging in Senkata-El Alto (BOLIVIA). Renewable Energy 8 Power Quality Journal, 7, April 2009. 